\title{
First-year university students' knowledge of academic misconduct and the association between goals for attending university and receptiveness to intervention
}

\author{
Jed Locquiao ${ }^{1^{*}}$ (D) and Bob Ives ${ }^{2}$
}

* Correspondence: jed.locquiao@ mnstate.edu

${ }^{1}$ School of Teaching and Learning, Minnesota State University,

Moorhead 56563, USA

Full list of author information is available at the end of the article

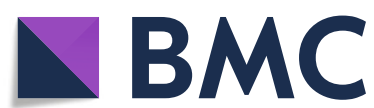

(c) The Author(s). 2020 Open Access This article is licensed under a Creative Commons Attribution 4.0 International License, which permits use, sharing, adaptation, distribution and reproduction in any medium or format, as long as you give appropriate credit to the original author(s) and the source, provide a link to the Creative Commons licence, and indicate if changes were made. The images or other third party material in this article are included in the article's Creative Commons licence, unless indicated otherwise in a credit line to the material. If material is not included in the article's Creative Commons licence and your intended use is not permitted by statutory regulation or exceeds the permitted use, you will need to obtain permission directly from the copyright holder. To view a copy of this licence, visit http://creativecommons.org/licenses/by/4.0/. The Creative Commons Public Domain Dedication waiver (http://creativecommons.org/publicdomain/zero/1.0/) applies to the data made available in this article, unless otherwise stated in a credit line to the data. 
operation of HEIs to graduate students who, having been vetted for, can support the intellectual and workforce health of constituent communities.

The harm of AM is aggravated by its high prevalence: $50-80 \%$ of students, across US and international HEIs, have reported engaging in AM behaviors during university (Brimble and Stevenson-Clarke 2005; Haines et al. 1986; Hughes and McCabe 2006; Ives et al. 2017; Cizek 1999; McCabe and Treviño 1993, 1995, 1997; McCabe et al. 2001, 2012; Stern and Havlicek 1986). The incidence and harm of AM is further undermined by the lack of coordinated and proactive HEI responses to AM (Graham et al. 1994; Jendrek 1989; McCabe and Treviño 1993; McCabe et al. 2012). HEI faculty have been faulted for being permissive with AM cases if not outright ignoring them. When interventions or consequences are levied in AM cases, they often amount to idiosyncratic punishments from individual instructors. The lack of systematic HEI response to AM is exacerbated by the fragmented body of empirical research which vets best practices to address AM (Ives and Nehrkorn 2019).

Ample research literature has focused on identifying student-level variables that predict incidence of academic misconduct. Factors like younger enrollment age, male gender, lower self-concept, pressure for good grades, neutralizing rationales (e.g., denial of victim), past underachievement, witnessing peer AM, and confidence in not getting caught or punished have been found to relate with greater incidence of AM (Anderman and Danner 2008; Aronson and Mettee 1968; Jordan 2001; McCabe et al. 2001, 2012; McCabe and Treviño 1993, 1997; Murdock and Anderman 2006; Murdock et al. 2004; Rettinger and Kramer 2009). Knowledge of AM behaviors/consequences and motivation are two prominent student-level factors that have been used to explain AM. Research has found that university students often report little awareness or understanding of not just AM overall, but AM as it relates to HEI policies and procedures (McCabe et al. 2012). Furthermore, university students disagree on what behaviors constitute AM the egregiousness of such behaviors, and the correct response to such behaviors (Ashworth et al. 1997; Burrus et al. 2007; Carpenter et al. 2010; Jordan 2001; Keener et al. 2019).

However, studies on students' AM knowledge bear a persistent methodological issue where they amount to recognition tasks that have students rate/rank perceived permissiveness, egregiousness, or personal history of engaging in specific behaviors of AM. As noted by Ashworth et al. (1997), recognition tasks presume students received similar instructional experiences and acquired similar background knowledge on AM to think and evaluate AM in the same operational terms and conceptual models as researchers. A student may have rated self-plagiarism as unacceptable not because they learned anything about it or experienced it, but because a given measurement identified selfplagiarism as an AM behavior. Inversely, a student may have rated self-plagiarism as permissible because their life and learning experiences have not contested selfplagiarism which in turn created a conceptual model where AM does not include selfplagiarism.

Inferences from recognition tasks risk being reflections of agreement with researchers' AM knowledge rather than direct observations of students' AM knowledge. Students report limited AM knowledge when asked to evaluate AM definitions and scenarios presented by researchers; but how do students comprehend their own working terms and models of AM? This methodological gap is a problem because it distorts 
inferences on student AM knowledge which can skew the focus of intervention efforts. For example, say an HEI conducted a recognition task survey and found that many students affirmed cheating is bad and harmful. Furthermore, the survey found that many students expressed ambivalence in reporting their friends. The results could not speak to students' knowledge in how cheating is bad and harmful. The results also could not speak to students' familiarity with reporting procedures. In such an instance, HEIs could inadvertently waste resources teaching students on the value of the reporting $\mathrm{AM}$, when instruction on the forms, consequences, and reporting procedures to AM would better support students.

Another other major characteristic that has been consistently linked to AM is student goal orientation for learning. Considerable research on this trait examined student goal orientation and AM through the mastery/performance dichotomy under the achievement goal theory (AGT) framework. Mastery orientation refers to engaging in an activity for the sake of improving in the associated tasks of that activity; and performance orientation refers to engaging in an activity to demonstrate competence in comparison to others (Ames 1992; Ames and Archer 1988; Elliott and Dweck 1988; Murdock and Anderman 2006). In the context of AM, students with performance orientations have been found to engage in higher rates of AM (Anderman et al. 1998; Anderman and Danner 2008; Genereux and McLeod 1995; Huss et al. 1993; Jordan 2001; Murdock et al. 2001; Weiss et al. 1993). This trend is exacerbated by classroom environments that emphasize performance over mastery learning (Murdock et al. 2004, 2007).

One gap in the research on AM and goal orientations is that it has primarily focused on AGT over other frameworks. This is problematic because AGT construes goals into a mastery/performance dichotomy; it does not clearly allow for analysis of other goals which come with developmental maturity like doing activities to acquire a certain level of income; work in a stable career; form a personal identity; make a difference in the community, etc. These are goals that gain salience among university-going individuals, but do not neatly fit a mastery/performance dichotomy. Examining these emergent goals may yield nuanced relationships to AM incidence, reasons, and intervention efforts.

AM research can use another major framework in goal orientation to accommodate the greater variety of motivators: Goal Content Theory (GCT) which falls under the bigger umbrella of Self-Determination Theory (SDT) (Deci and Ryan 1985, 1991, 2000; Kasser and Ryan 1993, 1996; Sheldon et al. 2004; Vansteenkiste et al. 2006, 2010). SDT describes the "why" of behaviors. It stipulates that individuals engage in activities along a continuum of regulated motivation (from extrinsic to intrinsic) which reflects the extent an activity is self-initiated or prodded by some external factor. Self-initiated activities prove more psychologically fulfilling as they meet an innate human need to exercise autonomy (self-valued and self-chosen activity).

Goal Content Theory, as a sub-theory, supports SDT by describing the "what" of behaviors (Kasser and Ryan 1993, 1996; Schmuck et al. 2000; Sheldon et al. 2004; Vansteenkiste et al. 2006, 2010). It asserts that as much there exist different degrees of regulated motivation, there also exist different goals (motivators) that direct motivation. And that goals follow an intrinsic/extrinsic pattern as well. Extrinsic goals refer to outcomes or conditions whose fulfillment depends on external recognition or reward (e.g, by check, by organization, or by peers) and include the goals of accumulating 
wealth, attaining a career, and acquiring fame/image. Intrinsic goals refer to outcomes or conditions derived from one's interest or satisfaction in the inherent tasks of an activity. Unlike extrinsic goals, fulfillment of intrinsic goals does not depend on external recognition or reward but instead depends on individual evaluation. Intrinsic goals are understood to be more fulfilling because they preserve autonomy and promote two other innate human needs for competency (skills/knowledge to act on one's interests) and relatedness (supporting close and caring relationships). Intrinsic goals include personal growth, supporting close relationships (e.g., families/friends), and contributing to the community.

Compared to AGT-based research, there exists limited research examining AM in clear reference to GCT-SDT premises (Murdock and Anderman 2006). One study conducted by Kanat-Maymon et al. (2015) found that student's lack of fulfillment in autonomy, competency, and relatedness predicted higher rates of AM. Another study conducted by Park (2019) found that one type of extrinsic goal content (wealth accumulation) predicted higher rates of cheating over one type of intrinsic goal content (self-improvement). Inferences must come from other studies which indirectly referenced GCT-SDT. Such studies have linked higher rates of cheating with the promise of reward incentives, the desire for peer approval, and the pursuit of career and salary prospects (Covey et al. 1989; Lobel and Levanon 1988; Newstead et al. 1996).

Consequently, AM to motivation literature generally points to an overall pattern where certain types of goals relate to higher rates of AM. But there is a gap where research has yet to disaggregate goals at the university level when students act on a greater range of motivations beyond the mastery/performance dichotomy. Evidence of different relations between AM to certain kinds of extrinsic/intrinsic motivation may support more accurate profiles of AM incidence, reasons, and intervention efforts. Understanding is especially critical in guiding the design of interventions because research has pointed to how outward goal orientations relate to less cognitive engagement with instructional tasks which in turn invites superficial learning (Meece et al. 1988; Nolen 1988; Pintrich 2000).

\section{Purpose of study and research questions}

The present study seeks to add to empirical literature by addressing above gaps in AM research. The first gap is the methodological issue where student knowledge of AM is often inferred from recognition tasks to identify or rate AM behavior. Recognition tasks presume that students understand AM to the same operational terms and conceptual models of researchers. A student may have rated self-plagiarism as unacceptable not because they learned anything about it or experienced it, but because the measurement identified self-plagiarism as an AM behavior. Inversely, a student may have rated selfplagiarism as permissible because their life and learning experiences have not contested self-plagiarism which in turn created a conceptual model where AM does not include self-plagiarism. Inferences from recognition tasks risk being reflections of agreement rather than direct estimates to what students know.

To address this gap, the present study used a production task rather than a recognition task to determine the quality of AM knowledge among first-year university students. The production task prompted students to write on what they knew about references/citations and cheating. Open-ended responses were inferred to generate 
estimates to more complete and more complex levels of understanding because writing permitted selecting pertinent knowledge, elaborating on points, and creating examples-all of which reflect more robust background knowledge on AM. In doing so, this study seeks to add to empirical knowledge on the quality of AM knowledge students bring to bear at the start of their university careers.

The second gap is the lack of research that relates AM to GCT-SDT's extrinsic and intrinsic goal contents. Analysis of AM to motivation has primarily used the mastery/ performance dichotomy of AGT to conclude-with ample empirical evidence-that outward performance motivations relate to higher rates of AM. However, the dichotomy does not neatly accommodate the developmental shift into university as students engage in more varied behaviors for myriad reasons like having a certain income level, attaining a certain position, or supporting the community. There may exist more nuanced relations between AM and motivation that can be explained by other major frameworks like GCT-SDT which not only incorporate mastery and performance into their models (intrinsic and extrinsic goals respectively) but permit the analysis of other motivators.

To address this gap, the study prompted first-year university students with openended responses to write about their goals going to university and analyzed their responses to GCT-SDT premises. Furthermore, analysis was conducted to determine the extent that discrete goals associated with receptiveness to AM intervention. The reason for focusing on receptiveness to intervention came from research pointing to how intrinsically-motivated students tackle instructional activities with greater cognitive engagement (Meece et al. 1988; Nolen 1988). To our knowledge, no research has yet examined the relation between motivation and reception to AM intervention. This is problematic because motivation profiles may moderate the success of AM interventions. Consequently, to address both gaps the present study asked two research questions with attendant hypotheses:

Question 1. What quality of AM knowledge do first-year university students have in terms of references/citations and cheating on assignments/tests?

Question 2. What associations exist between overall and select extrinsic/intrinsic goals as understood by GCT-SDT and receptiveness towards AM intervention among firstyear university students?

\section{Method}

\section{Research design}

The study used a descriptive-correlational research design to guide its data collection, analysis, and interpretation of results (Price et al. 2017). This design best fit the research questions which asked frequencies behind the kinds of knowledge, motivations, and reception held by first-year university students. The present study is descriptive rather than experimental because it did not seek to attribute a causal relationship between variables; and because it measured and analyzed the above items without manipulation of group assignment or time. The study is correlational because it seeks to determine the extent that certain kinds of motivation overall and discrete associated with receptiveness to AM intervention. 


\section{Sample characteristics}

The study examined academic misconduct knowledge, extrinsic/intrinsic goals for attending university, and receptiveness to AM intervention among first-year students enrolled in a Western US public university-a research-intensive and doctoral-granting institution. The university organized specific majors (early childhood education, accounting, etc.) under the purview of broader administrative units called colleges. Students in the sample all enrolled in the same university, but for this study they were also classified under one of two colleges (business or education) depending on their major. As mentioned, research points to a persistent lack of understanding and agreement on AM among university students (Ashworth et al. 1997; Burrus et al. 2007; Jordan 2001; McCabe et al. 2012). Therefore, focusing on first-year students adds upon empirical knowledge by clarifying how university students understand AM at a critical juncture of academics before habits set them towards a trajectory of academic integrity or misconduct.

Typical demographic variables were not disclosed with the dataset because the online portion of training did not ask for students' demographic variables. It is inferred then that the students comprised young adults ranged 18-22 years old and approximated the social characteristics of the constituent region. The initial dataset comprised 444 student cases split between a business college and education college. Researchers deleted 88 cases that did not answer prompts related to the research questions, so the final analytic sample comprised 356 students between a business college $\left(n_{1}=270\right)$ and education college $\left(n_{2}=86\right)$. Post hoc power analysis using $G^{*}$ Power concluded that the sample size yielded power level $\beta=0.998$, which surpassed education research conventions in detecting moderate associations, Cramer's $\mathrm{w}=0.30$, set to $\alpha=0.05$ (Ellis 2010; Faul et al. 2007; Lipsey et al. 2012). In other words, significant moderate associations would reflect true associations $99.8 \%$ of the time.

\section{Intervention, data collection, and codebook}

AM intervention and data collection were conducted through the online learning management system of WebCampus. The intervention was delivered as an asynchronous online session. Both authors of this study designed and oversaw implementation of the intervention. As illustrated with Fig. 1, it entailed a sequence of modules that covered major topics to AM: behavioral definitions to AM, examples of AM in and beyond the

\begin{tabular}{|c|c|c|c|c|c|}
\hline BEFORE AM INTERVENTION & \multicolumn{4}{|c|}{ DURING AM INTERVENTION CONTENT } & AFTER AM INTERVENTION \\
\hline Introduction Module & $\begin{array}{l}\text { Topic } 1 \\
\text { Module }\end{array}$ & $\begin{array}{l}\text { Topic } 2 \\
\text { Module }\end{array}$ & $\begin{array}{l}\text { Topic } 3 \\
\text { Module }\end{array}$ & $\begin{array}{l}\text { Topic } 4 \\
\text { Module }\end{array}$ & Check-In Module \\
\hline \multicolumn{6}{|c|}{ Student progression path } \\
\hline $\begin{array}{l}\text { Preliminary Free Response } \\
\text { Questions* }\end{array}$ & $\begin{array}{c}\text { Free } \\
\text { Response } \\
\text { Questions }\end{array}$ & $\begin{array}{c}\text { Free } \\
\text { Response } \\
\text { Questions }\end{array}$ & $\begin{array}{c}\text { Free } \\
\text { Response } \\
\text { Questions }\end{array}$ & $\begin{array}{c}\text { Free } \\
\text { Response } \\
\text { Questions }\end{array}$ & $\begin{array}{l}\text { Summative Free Response } \\
\text { Questions** }\end{array}$ \\
\hline \multicolumn{6}{|c|}{$\begin{array}{l}\text { *Three questions from this section selected for analysis } \\
{ }^{* *} \text { One question from this section selected for analysis }\end{array}$} \\
\hline \multicolumn{6}{|c|}{ Fig. 1 Schedule for Free Response Prompts and Intervention } \\
\hline
\end{tabular}


university setting, factors linked to $\mathrm{AM}$, and consequences of $\mathrm{AM}$ in and beyond the university setting. Completing one module unlocked the next module in succession. Each module presented content and assessed learning to elements of direct instruction (e.g., explanations and quizzes) and constructivist instruction (e.g., real-life connections and reflection prompts).

Students answered several free-response prompts before, during, and after accessing formal AM content in the intervention. For the purposes of this study, student responses to just four prompts were selected for analysis. As illustrated by Fig. 1, the first three prompts were presented and answered before accessing AM intervention content; and the last prompt was presented and answered after accessing the entire sequence of AM intervention content. The four prompts asked the following questions:

(a) What do you remember learning from instruction on citations/references?

(b) What do you remember learning from instruction on test/assignment cheating?

(c) What is your most important motivation/goal for attending university?

(d) Please describe any content that you found to be a waste of your time. Why do you feel it was a waste of your time?

Answers to the above questions represented students' citation/reference knowledge, cheating knowledge, motivation/goals for attending university, and receptiveness to AM intervention. The online learning system generated a spreadsheet of student responses in preparation for coding and statistical analysis using IBM-SPSS 25.

The study identified student responses to open-ended prompts as the unit of analysis. Student responses served as raw qualitative data because they carried meaning in terms of non-numerical patterns (e.g., words and sentences). To support statistical inferences on student knowledge of AM, researchers used Quantitative Content Analysis (QuantCA) as described by Neuendorf (2002) to transform student responses into categorical values. Quant-CA allows written data to be interpreted as message units to discrete patterns, represented by a numerical code, which can be counted and tested through statistical analyses. Quant-CA diverges from other forms of thematic analysis because applies positivist assumptions, quantitative methods, and hypothesis-testing on qualitative data.

Quant-CA prompts researchers to create a codebook of a priori codes to test message patterns rather than affirm patterns after the fact. Therefore, researchers prepared a codebook (see Additional file 1) that explained the criteria for assignment to certain categorical values and disclosed justifications for criteria. Researchers coded each item response to the extent they met the criterion of a priori codes. However, in recognition of the iterative nature of qualitative coding, the study also used Second Cycle Coding as outlined by Saldaña (2015) to record emergent patterns that did not fit the initial a priori codes. In doing so, the study preserved the intent to test a priori patterns while recognizing unexpected patterns.

The coding process entailed two major steps: drafting codebook criteria and checking codebook criteria. Throughout the coding process, both authors had access to the full cohort of responses. Author 1 drafted codebook criteria over multiple revisions using the two-cycle coding pattern. With the first-cycle, Author 1 identified a priori codes from research literature on GCT-SDT and screened the full cohort of responses to 
those codes. Over the course of screening, Author 1 identified emergent codes beyond the initial parameter of a priori codes. With the second cycle, Author 1 again screened the full cohort of responses to those emergent codes.

After Author 1 conducted a complete set of first- and second-cycle coding, Author 1 presented the full codebook criteria to Author 2 in preparation of interrater reliability check. At this point, both authors had access to the most recent version of the codebook criteria. For interrater reliability check, Author 2 was assigned to code a randomized sample comprised of $10 \%$ of the full cohort of responses. Convention in quantitative content analysis identified $10 \%$ as an appropriate sample to large qualitative datasets (Neuendorf 2002). After Author 2 conducted first- and second-cycle coding on the sample, Author 2 submitted the coded sample to Author 1 to calculate interrater reliability. Cohen's Kappa values met moderate agreement (41.90) at the low end to almost perfect agreement at the high end (88.20) per research convention (Landis and Koch 1977).

\section{Variables of interest (construct and coding)}

Three variables were selected as the focus of this study. The first variable was student knowledge of AM in terms of citations/references and cheating on assignments/tests. As described in the codebook, student knowledge on citations/references referred to valid responses that either (a) referenced the salient idea of accurate attribution of others' work or (b) mentioned a situation or procedure related to appropriate citations/ references. Student knowledge on test/assignment cheating referred to valid responses that either (a) referenced the salient idea of unauthorized or undisclosed means that confer advantage to a student in assignments and tests or (b) mentioned a situation or procedure related to cheating. The rationale for accurate attribution of others' work, undisclosed means that confer advantage, and a situation/procedure related to the above came from AM research literature which generally defined plagiarism as an issue of accurate attribution; generally defined cheating as an issue of unauthorized coursework advantage; and has described how plagiarism and cheating can manifest in many different forms (McCabe et al. 2012).

To determine the quality of student knowledge, understood as complexity and completeness, responses were marked as [Beginner] or [Advanced] if they fulfilled one or both criteria. The rationale for distinguishing between beginner and advanced knowledge was informed by research in educational psychology which points to elaboration (following up claims with supporting claims) as a mark of deep structural knowledge over passing superficial knowledge (Anderson et al. 2001; Gobbo and Chi 1986; National Research Council 2000). As demonstrated with the codebook, interpretation of responses followed a charitable approach because criterion language qualified responses as beginner knowledge if they at minimum referenced any pertinent idea or situation. Furthermore, criterion language qualified responses as advanced knowledge if they gave any level of elaboration (no matter how terse). During the first phase of coding, student responses to both types of AM knowledge generated themes of procedure, consequence, and value that did not fit a priori codes. These themes were turned into emergent codes which guided iterative coding phases.

The second variable was student goal content in attending university. As described in the codebook, student goal content referred to valid responses that yielded extrinsic, 
intrinsic, or both types of goal contents. Responses marked as [Extrinsic] met the criterion of mentioning an outcome or condition from attending university whose fulfillment depended upon external reward or recognition. Examples of this sort of goal included accumulating wealth, attaining a career, and acquiring approval. Responses marked as [Intrinsic] met the criterion of mentioning an outcome or condition whose fulfillment derives from one's interest or satisfaction in the inherent tasks of attending university. Intrinsic contrasts with extrinsic in that there exists no external mechanism to meet the outcome or condition. Examples of intrinsic goals included personal growth, supporting close relationships, and contributing to the community. Responses marked as [Both] met both criterion by mentioning both extrinsic and intrinsic goal contents.

Second cycle coding of student goal content responses yielded seven emergent codes which represented subtypes of extrinsic and intrinsic goal contents: financial success, career attainment, degree/credential/education, fame/social approval, community contribution, personal improvement/interest/value, and supporting affiliation. Responses were marked for each goal they mentioned, so it was possible for a response to have multiple subtypes (e.g., a response marked with career attainment, community contribution, and fame/social approval). To prepare the data for Chi-Square testing, each subtype variable was further transformed into a dichotomous variable of $[0,1]$ to represent cases that did or did not qualify for each subtype. The rationale to distinguish cases to the above criterion came from Goal Content Theory (GCT) under the umbrella framework of Self-Determination Theory (SDT) (Kasser and Ryan 1993, 1996; Vansteenkiste et al. 2006, 2010). GCT-SDT stipulates that some goal contents have an inward orientation in that their fulfillment is determined by individual evaluation; whereas other goals have an extrinsic orientation in that their fulfillment depends on external reward or recognition. The subtypes were informed by GCT-SDT research that has pointed to amassing wealth; obtaining a career; and attaining a degree/credential/education as extrinsic goals and has pointed to community contribution; personal improvement/interest/value; and supportive affiliation as intrinsic goals. Authors wish to explain that education under extrinsic goals referred to the pattern where student responses described education as a contingent output which awaits students at the end of attending university. Responses coded as education did not describe attending university in terms of personal interest or satisfaction from the learning process-learning for learning sake-which would have been coded under intrinsic goal as personal interest.

The third variable was student receptiveness towards the AM intervention. As shown in the codebook, student receptiveness referred to valid responses that presented either neutral/welcome statements or indignant/resentful statements in their evaluation of the AM intervention following completion. Receptiveness was construed in reference to both dictionary definition and comparable Big Five Personality trait of Openness to Experience as an affective state of understanding, tolerance, and appreciation for ideas and experiences (Merriam-Webster 2020; Roccas et al. 2002). Responses marked as [Neutral/welcome] presented items that either amounted to (a) actionable feedback to improve the AM training or (b) expressed utility in or appreciation for the AM training. Responses marked as [Indignant/resentful] presented items that either stated the (a) AM training or (b) AM content was unnecessary, useless, or irrelevant because of past 
instruction on $\mathrm{AM}$; addressing $\mathrm{AM}$ is a pointless endeavor; or $\mathrm{AM}$ just not being important. The rationale in distinguishing between neutral/welcome and indignant/resentful reception was to analyze responses marked by antipathy. By doing so, testing was expected to yield clearer patterns between outright negative receptiveness and goal contents.

\section{Data analysis}

To answer the research questions, this study used frequency counts and Chi-Square Test of Associations. Chi-Square testing examines association by verifying, through its namesake $X^{2}$ statistic, the extent that the observed frequency counts given two nominal variables proves independent of expected frequency counts (Cohen 1988). For this study, $3 \times 2$ and $2 \times 2$ Chi-Square Tests were conducted. The second research question asked for overall associations between extrinsic, intrinsic, and both types of goal contents to neutral/welcome or indignant/resentful receptiveness of intervention which translated to 3 levels in the former and 2 levels in the latter. The second research question asked for discrete associations between select subtypes of goal content to receptiveness of intervention. The three most represented subtypes had enough responses to meet the assumption of adequate cell counts to Chi-square testing. To meet the assumption of independence of observations, each discrete subtype level was transformed into a dichotomous variable with 2 levels to represent whether a response did or did not convey a given subtype.

\section{Results}

Tables 1, 2, 3 and 4 present frequency counts with example student responses. Several patterns emerge from the results. First, the great majority of students reported beginner knowledge in both citation/reference and cheating on tests/assignments responses. Furthermore, a non-trivial number of students wrote either irrelevant or non-applicable statements to both knowledge items (32.3\% and $21.6 \%$ respectively). Second cycle coding found that in terms of citations/references, most responses referred to procedures; but in terms of test/assignment cheating, most responses referred to consequences-with a sizeable contingent citing values as well.

Second, the great majority of students cited extrinsic goals for attending university. Career attainment and Degree/credential/ education proved the most represented subtypes of extrinsic goals ( $49.7 \%$ and $43.3 \%$ respectively), whereas Personal improvement was the most represented subtype intrinsic goal (20.2\%). Third, most students expressed neutral or welcome receptiveness towards the intervention; but a sizeable contingent (21\%) expressed indignation/resentment over having participated. And fourth, as shown in Tables 5 and 6. Chi-square statistics reported no statistically significant association (and negligible effect sizes) between overall goal content-extrinsic, intrinsic, and both-to receptiveness of AM, intervention $\chi^{2}(2)=1.726$; Cramer's $V=$ $0.076, p>0.05$. Furthermore, Chi-square statistics reported no statistically significant association (and negligible effect sizes) between the three most represented subtypes of goal contents-career attainment, degree/credential/ education, and personal improvement/ interest/value-to receptiveness of AM intervention. 
Table 1 Citations/reference knowledge

\begin{tabular}{|c|c|c|}
\hline \multicolumn{3}{|c|}{ What do you remember learning from instruction on citations/references? } \\
\hline & n (\%) & \\
\hline \multicolumn{3}{|c|}{ A priori codes } \\
\hline \multirow[t]{2}{*}{ N/A } & $115(32.3)$ & $\begin{array}{l}\text { "They are essential going into the work field. They are your past employers } \\
\text { or other leaders who can speak well for your name and really boost your } \\
\text { resume." (Reference } 968, \text { CoB) }\end{array}$ \\
\hline & & $\begin{array}{l}\text { "References can be used as supportive information or background help." } \\
\text { (Reference } 312, \mathrm{CoE} \text { ) }\end{array}$ \\
\hline \multirow[t]{2}{*}{ Beginner } & $218(61.2)$ & $\begin{array}{l}\text { "You should include citations in all work that was not yours." } \\
\text { (Reference } 712, \mathrm{CoB} \text { ) }\end{array}$ \\
\hline & & $\begin{array}{l}\text { "MLA format, mostly. How to format in text citations. Works cited page." } \\
\text { (Reference } 141, \mathrm{CoE} \text { ) }\end{array}$ \\
\hline \multirow[t]{2}{*}{ Advanced } & $23(6.5)$ & $\begin{array}{l}\text { "I learned that if I wrote down anything that didn't come from my own } \\
\text { knowledge or free-thinking, I needed to provide a source to show where I } \\
\text { got that information from. Common examples would be statistics I had to } \\
\text { look up, a certain sentence of something being described that I used from } \\
\text { an article. I had to provide the source for where I got that information. I } \\
\text { learned to use in-text citations in my writings, and that after my essay was } \\
\text { done I would include a Citations page after that listing the whole citation } \\
\text { in its entirety. The Citations page would include more } \\
\text { information on the author, possibly the website where the article is from, } \\
\text { the database I received the information from, the publishing date, etc. I } \\
\text { learned that not citing when supposed to is against the law and results in } \\
\text { plagiarism, which has serious consequences - especially for a student." } \\
\text { (Reference } 916, \text { CoB) }\end{array}$ \\
\hline & & $\begin{array}{l}\text { "I remember how to cite what an author had stated in their book or blog } \\
\text { in a paragraph. If I had used on of their facts to help my thesis, I would } \\
\text { put their last name and the date the source was published. I also } \\
\text { remember that when citing a source I have to put the authors last name, a } \\
\text { comma, and then their first. Then I have to put the title of their work with } \\
\text { a period, and then list the website I found the source on if there was one." } \\
\text { (Reference } 409, \text { CoE) }\end{array}$ \\
\hline
\end{tabular}

\section{Emergent codes}

Procedure

$222(62.4)$

Consequences

$18(5.1)$

Values
"What I learned about citations was the fact of how to properly use them correctly...There are a variety of styles of citations and/or references to acknowledge from MLA, APA, or Chicago Notes \& Bibliography. Not to mention, but which style of citation is recommended to use based off what you're writing. For example, a English writing assignment would be MLA. Citations include specific dates, authors, publishers, year, website, and much more." (Reference 572, CoB)

"For the most part, I remember using citation machine to make the most accurate citations. I used what information the site I needed to reference gave me, and plugged that into the inputs on the citation website. Since every teacher I had wanted a different format, I never learned how to do one specific style." (Reference 195, CoE)

"Integrity violations can lead to academic probations, holds, zero on assignments, and failed classes" (Reference 083, CoB)

"if you are caught cheating in any type there will be repercussions" (Reference 909, CoE)

"Without any citations or references to the real person with the original work means that your stealing their work. Also that colleges don't play around with this type of stuff." (Reference 320, CoB)

"ALWAYS cite, even if you paraphrase. Make sure you cite in the format a professor asks for. Always uses reliable sources." (Reference 567, CoE).

\section{Discussion and limitations}

Ample empirical research has outlined the myriad student variables that relate to academic misconduct. However, two variables have been comparatively unexamined: the quality of background knowledge university students have on AM and the relation 
Table 2 Cheating on tests/assignments knowledge

\begin{tabular}{|c|c|c|}
\hline \multicolumn{3}{|c|}{ What do you remember learning from instruction on cheating in tests/assignments? } \\
\hline & n (\%) & \\
\hline \multicolumn{3}{|l|}{ A priori codes } \\
\hline \multirow[t]{2}{*}{ N/A } & \multirow[t]{2}{*}{$77(21.6)$} & "I did not learn anything on this topic." (Reference $684, \mathrm{CoB}$ ) \\
\hline & & "I didnt" (Reference 596, CoE) \\
\hline \multirow[t]{2}{*}{ Beginner } & \multirow[t]{2}{*}{$273(76.7)$} & $\begin{array}{l}\text { "Cheating on exams or assignments is prohibited and can } \\
\text { lead to failure of the assignment or test." Reference } 053, \mathrm{CoB} \text { ) }\end{array}$ \\
\hline & & $\begin{array}{l}\text { "Cheating is very bad, and you shouldn't do it" } \\
\text { (Reference } 618, \text { CoE) }\end{array}$ \\
\hline \multirow[t]{2}{*}{ Advanced } & \multirow[t]{2}{*}{$6(1.7)$} & $\begin{array}{l}\text { "my parents helped give me good ethics even through high } \\
\text { school my grades where never top of the class but it was the } \\
\text { correct representation on how I worked and my own } \\
\text { knowledge on a subject matter I didn't cheat through it to } \\
\text { maintain a great GPA but went through it with my own } \\
\text { knowledge and was able to find what I need to work on and } \\
\text { its thanks to them that I understand that cheating is } \\
\text { unacceptable." (Reference 170, CoB) }\end{array}$ \\
\hline & & $\begin{array}{l}\text { "I learned that cheating does not benefit you in the long run } \\
\text { because if you don't know the information then you won't } \\
\text { know it in the future. Cheating is also academic dishonesty } \\
\text { and it is basically not using your own thinking on } \\
\text { assignments." Reference 484, CoE) }\end{array}$ \\
\hline \multicolumn{3}{|l|}{ Emergent codes } \\
\hline \multirow[t]{2}{*}{ Procedure } & \multirow[t]{2}{*}{$32(11.0)$} & $\begin{array}{l}\text { "Absolutely no cheating. Using another students work to get } \\
\text { answers, coping things down, looking over a shoulder, etc. } \hat{A} \\
\text { all prohibited" (Reference } 782, \text { CoB) }\end{array}$ \\
\hline & & $\begin{array}{l}\text { "Don't cheat on homework, quizzes, and tests. You need to } \\
\text { cite your sources for writing or it is cheating." } \\
\text { Reference } 479, \text { CoE) }\end{array}$ \\
\hline \multirow[t]{2}{*}{ Consequences } & \multirow[t]{2}{*}{$190(53.4)$} & $\begin{array}{l}\text { "I told not to cheat and if you chose to cheat you would get } \\
\text { points taken off your assignment or test. I learned that you } \\
\text { shouldn't cheat on assignments or test." (Reference } 872, \text { CoB) }\end{array}$ \\
\hline & & $\begin{array}{l}\text { "you will get } 0 \text { for the assignment or even the course and } \\
\text { then it will be reported to the school. When you're caught } \\
\text { cheating this will go on your record. You may not be allowed } \\
\text { to continue being a student at the university. You might have } \\
\text { to take a academic honesty course" Reference } 921, \mathrm{CoE} \text { ) }\end{array}$ \\
\hline \multirow[t]{2}{*}{ Values } & \multirow[t]{2}{*}{$121(34.0)$} & $\begin{array}{l}\text { "You're only cheating on yourself if you cheat on exams, tests } \\
\text { and life related situation." (Reference } 602, \text { CoB) }\end{array}$ \\
\hline & & "Cheating is bad. Don't cheat." (Reference 153, CoE) \\
\hline
\end{tabular}

between goals for going to university and reception to intervention on AM. The study findings contribute to research literature by using a production task to gauge students' conceptual knowledge of AM. The study findings also contribute to the research literature by relating goal contents, as understood by GCT-SDT, to receptiveness of AM intervention.

Two major inferences emerge from the results. Frequency counts support the claim that most students start university with basic knowledge of academic misconduct, in terms of citations/references and cheating. The conspicuous lack of advanced knowledge and high rates of N/A knowledge corroborate prior empirical literature which found university students have limited understanding of the basic terms, processes, and situations of AM (Ashworth et al. 1997; Jordan 2001; McCabe et al. 2012). Emergent codes add nuance with highlighting how students prioritized procedure items (e.g., citation styles) when asked of citation/references, but prioritized consequence items (e.g., 
Table 3 Goal contents for attending college

\begin{tabular}{|c|c|c|}
\hline \multicolumn{3}{|c|}{ What is your most important motivation/goal for attending university? } \\
\hline & n (\%) & \\
\hline \multicolumn{3}{|c|}{ A priori codes } \\
\hline \multirow[t]{2}{*}{ N/A } & $22(6.2)$ & "Future success." (Reference 122, CoB) \\
\hline & & "I want to be successful in my future life." (Reference 621, CoE). \\
\hline \multirow[t]{2}{*}{ Extrinsic } & $228(64.0)$ & $\begin{array}{l}\text { "Getting a degree and being able to get a high paying job" } \\
\text { (Reference } 451, \mathrm{CoB} \text { ) }\end{array}$ \\
\hline & & "Job and money" (Reference 798, CoE) \\
\hline \multirow[t]{2}{*}{ Intrinsic } & $41(11.5)$ & $\begin{array}{l}\text { "To better myself by putting myself through hard situations and } \\
\text { pushing myself to grow as a person." (Reference } 875, \mathrm{CoB} \text { ) }\end{array}$ \\
\hline & & $\begin{array}{l}\text { "I want to learn how to be an adult as well as an amazing } \\
\text { teacher to kids who need a great one the most." } \\
\text { (Reference } 853, \mathrm{CoE} \text { ) }\end{array}$ \\
\hline \multirow[t]{2}{*}{ Both } & $65(18.3)$ & $\begin{array}{l}\text { "My motivation is to improve myself and start my career" } \\
\text { Reference } 917, \text { CoB). }\end{array}$ \\
\hline & & $\begin{array}{l}\text { "My parents and being a role model for my family" } \\
\text { (Reference } 603, \mathrm{CoE} \text { ) }\end{array}$ \\
\hline
\end{tabular}

\section{Emergent codes}

Financial success

Career attainment

Degree/credential/education

Fame/social approval

Community contribution

Personal improvement/ interest/value

Supportive affiliation
57 (16.0) "My most important motivation for coming to [HEl] is to make money." (Reference 480, CoB)

"My most important motivation for attending university is to give me a higher chance of obtaining a well-paying, substantial job." (Reference 916, CoE)

177 (49.7) "Getting a degree to get a good job" (Reference 590, CoB)

"I want to better my sled and prosper not stay working at Taco Bell. I want to help people in my profession and I want to be a hell of a teacher!" (Reference 227, CoE)

154 (43.3) "I need to get my mba and make money" (Reference 969, CoB).

"To further my education and hopefully gain the ability to have a career in teaching." (Reference 852, CoE)

39 (11.0) "Make my parents proud and graduate." (Reference 427, CoB). "proving my family and peers wrong" (Reference 746, CoE)

18 (5.1) "my most important motivation is to start a business and open opportunities for employees" (Reference 333, CoB)

"My most important motivation for attending the university is to be a teacher. I want to be a teacher because I can then help kids and motivate them to be who they want to be in the future." (Reference 615, CoE).

72 (20.2) "For myself, to prove to myself that I can do anything that I set my heart out to do." (Reference 431, CoB)

"I want to achieve my degree in order to become a teacher, so I can make a difference in the world and follow what I feel is my callling." (Reference 547, CoE)

16 (4.8) "My biggest motivation for attending this university is to find higher education and have the opportunity to get a better job so that I can provide for, not only myself but also my mom and family." (Reference 404, CoB)

"My most important motivation for attending the university is to be a teacher. I want to be a teacher because I can then help kids and motivate them to be who they want to be in the future." (Reference 109, CoE) 
Table 4 Receptiveness to intervention on academic misconduct

\begin{tabular}{|c|c|c|}
\hline \multicolumn{3}{|c|}{ Please describe any content you found to be a waste of time. Why do you feel it was a waste of time? } \\
\hline & n (\%) & \\
\hline \multicolumn{3}{|l|}{ A priori codes } \\
\hline \multirow[t]{2}{*}{ N/A } & \multirow[t]{2}{*}{$38(10.7)$} & "My Econ 2 professors content" (Reference 153, CoB) \\
\hline & & $\begin{array}{l}\text { "I sometimes felt like math was a waste of time along } \\
\text { with science because I knew I didn't want to make any } \\
\text { of those subjects apart of my future career." } \\
\text { (Reference } 412, \text { CoB). }\end{array}$ \\
\hline \multirow[t]{2}{*}{ Neutral or welcome reception } & \multirow[t]{2}{*}{$241(67.7)$} & $\begin{array}{l}\text { "went over things a few too many times when once is } \\
\text { enough" (Reference } 418 . \mathrm{CoB} \text { ) }\end{array}$ \\
\hline & & $\begin{array}{l}\text { "I did not find any content to be a waste of my time, I } \\
\text { did think all the modules did take a long time, but I } \\
\text { took breaks here and there." (Reference } 109, \text { CoE). }\end{array}$ \\
\hline \multirow[t]{2}{*}{ Indignant or resentful reception } & \multirow[t]{2}{*}{$77(21.6)$} & $\begin{array}{l}\text { "I believe that the whole assignment was not a valuable } \\
\text { use of time. Only because I have received lessons, } \\
\text { lectures, and more explaining why not to cheat, } \\
\text { therefore it was repetitive of knowledge I was already } \\
\text { aware of." (Reference } 739, \text { CoB) }\end{array}$ \\
\hline & & $\begin{array}{l}\text { "what was presented in the module is common } \\
\text { knowledge that doesnt necessarily need to be } \\
\text { reiterated." (Reference } 874, \mathrm{CoE} \text { ) }\end{array}$ \\
\hline
\end{tabular}

point deductions) and value items (e.g., moral character) when asked of test/assignment cheating. Student knowledge of AM appears hampered by uneven ideas. Value items appear more salient in the context of cheating knowledge among students, but do not ground understanding of citation/references. In contrast, procedural items appear more salient in the context of citation/reference knowledge among students (different citation styles, conditions to specific citations, etc.) but do not ground understanding of cheating (forms of cheating, cheating detection, etc.).

The above finding presents a portrait where a typical first-year university student, upon learning that a course forbids plagiarism, would understand it to mean that the course merely expects use of a certain citation style or to review citation generators. But the student would not understand it to mean that the course expects honesty in placing one's ideas as a point within a greater line of ideas or that not citing invites punitive sanction. In contrast, that same typical first-year university student, upon learning that a course forbids cheating, would understand it to mean that the course merely reiterates a banal proposition, cheating is wrong, because years of instruction and warnings have instilled it as matter-of-fact. But that same student would struggle to describe what cheating entails or how cheating manifests across different situations.

Table 5 Chi-square $(3 \times 2)$ results on overall goal content to receptiveness of intervention

\begin{tabular}{lll}
\hline & $\begin{array}{l}\text { Neutral/Welcome } \\
\text { actual } \mathrm{n} \text { (expected } \mathrm{n})\end{array}$ & $\begin{array}{l}\text { Resentful/Indignant } \\
\text { actual } \mathrm{n} \text { (expected } \mathrm{n} \text { ) }\end{array}$ \\
\hline $\begin{array}{ll}\text { Overall Goal Content } \\
\text { Extrinsic }\end{array}$ & $150(154.5)$ & $54(49.5)$ \\
Intrinsic & $31(29.5)$ & $8(9.5)$ \\
Both & $47(43.9)$ & $11(14.1)$ \\
\hline $\mathbf{X}^{2}(2)=1.726 ;$ Cramer's $V=0.076, p>0.05$ & & \\
No cells with expected counts less than 5 & \\
$n=301$ applicable cases &
\end{tabular}


Table 6 Chi-square $(2 \times 2)$ results on subtypes of goal content to receptiveness of intervention

\begin{tabular}{lll}
\hline & $\begin{array}{l}\text { Neutral/Welcome } \\
\text { actual } \mathrm{n} \text { (expected } \mathrm{n})\end{array}$ & $\begin{array}{l}\text { Resentful/Indignant } \\
\text { actual } \mathrm{n} \text { (expected } \mathrm{n})\end{array}$ \\
\hline $\begin{array}{l}\text { Subtype of Goal Content } \\
\text { Career attainment }\end{array}$ & & \\
$\quad$ No & $108(105.3)$ & $31(33.7)$ \\
Yes & $120(122.7)$ & $42(39.3)$ \\
$\begin{array}{l}\text { Degree/credential/education } \\
\text { bo }\end{array}$ & $129(125.7)$ & $37(40.3)$ \\
No & $99(102.30)$ & $36(32.7)$ \\
Yes & & \\
$\begin{array}{l}\text { Personal improvement/ } \\
\text { interest/value }\end{array}$ & & $61(57.0)$ \\
No & $174(178.0)$ & $12(16)$ \\
Yes & $54(50)$ & \\
\hline
\end{tabular}

No cells with expected count less than 5

$n=301$ applicable cases

${ }^{\mathrm{a}} \mathrm{X}^{2}(1)=0.903 ;$ Cramer's $V=0.055, p>0.05$

${ }^{b} X^{2}(1)=0.777 ;$ Cramer's $V=0.051, p>0.05$

${ }^{c} X^{2}(1)=1.696 ;$ Cramer's $V=0.075, p>0.05$

Above patterns suggest that students carry surface-level knowledge of AM into their first year of university. Students wrote with uneven reference to procedures, consequence, and value items across both types of AM knowledge, which conveys that most students learn and organize their AM knowledge as piecemeal bits of information with little connections to other ideas or appreciation of broader context. Troublingly, this might amount to a generous estimate because the few students who did qualify for advanced knowledge did so from a coding that followed a charitable approach. Students do not just disagree on the terms, processes, and values of AM; they do not know the basic terms, processes, or values to AM. More troublingly, a non-trivial percentage of students found AM intervention superfluous or redundant despite having a shallow understanding of AM. This mismatch points to a parallel problem where inflated sense of competence sustains ignorance.

The immediate implication for HEIs then is that they should not presume first-year university students activate comparable knowledge on AM. What this means in practice is that HEIs may benefit more from designing and implementing interventions to develop common terminology, models, and culture to AM instead of focusing on just one aspect like academic consequences. The approach would use instructional tasks that encourage students to structure AM learning as a constellation of related ideas rather than patchwork facts or matters of convention. In practice, this could entail instruction on (a) definitions and examples to the most current understanding of how AM manifests across different subjects (humanities, education, engineering, etc.) or projects (term papers, portfolios, proposals, etc.); (b) how AM undermines the theory and practice of those different subjects and projects; (c) and how engaging in those different subjects and projects presume a certain baseline of academic integrity to function. Using a holistic approach would support more robust understanding as students connect their fragmented AM knowledge on procedures, consequences, and values as real-rather than unbound abstract-issues that support or diminish their goals for a university education. 
Chi-square results do not support the claim that goal contents, as understood by the GCT-SDT framework, relate to receptiveness to AM intervention. Despite the great majority of students citing extrinsic goal contents for attending university, associations yielded nonsignificant associations (with negligible effect sizes) between overall and specific subtypes of goal contents. The present findings extend empirical knowledge that while certain goal orientations coincide with higher rates of AM, goal orientations do not serve as a barrier to one unexamined aspect of AM-student regard towards related interventions (Anderman and Danner 2008; Jordan 2001; Kanat-Maymon et al. 2015; Murdock et al. 2001; Park 2019). An immediate implication for practice is that HEI may not need to tailor AM instruction (e.g., case studies that mention expulsion as an extrinsic outcome) to activate or align with university students' goal content profiles.

This is one of a handful of studies that surveyed first-year university students' conceptual knowledge of AM through a production task instead of recognition task. This is also one of a handful of studies that examined goal contents from the framework of GCT-SDT. This is the first study to relate student goal contents to receptiveness to AM intervention. It presents initial evidence that students' goal contents do not relate with regard for AM intervention. But this study has two major limitations. First, the study transformed qualitative data into numerical data which may have lost detail and nuance-hallmarks of qualitative data-in the process. It is an issue which invites threats of construct validity and interrater reliability to the numerical values. The researchers generated codes a priori and conducted interrater checks which helps guard against both threats; but the risk remains as an inherent feature to data transformation. Second, the study lacked pre- and post-intervention qualitative data. Items on AM knowledge and goal content were asked before content instruction; while the item on receptiveness to AM intervention was asked after content instruction. The present study reports frequency counts and associations at a single time and context. The study cannot determine changes to student responses over time. It may be the case that over the course of participating in the AM intervention, students remembered latent knowledge on AM, adjusted their goal contents, or shifted their regard.

\title{
Supplementary information
}

Supplementary information accompanies this paper at https://doi.org/10.1007/s40979-020-00054-6.

Additional file 1. Codebook.

\begin{abstract}
Abbreviations
AM: Academic misconduct; AGT: Achievement goal theory; GCT: Goal Content Theory; IBM-SPSS: International Business Machine Corporations-Statistical Package for the Social Sciences; QUANT-CA: Quantitative Content Analysis; SDT: Selfdetermination Theory
\end{abstract}

Acknowledgements

Authors wish to thank the university's transition program coordinator and staff for data access. And authors wish to thank anonymous reviewers for their insights and recommendations to improve this manuscript.

Declaration of interest

This study does not serve the financial interest or benefit of the authors. 
Funding

This study was not supported by any funding.

Availability of data and materials

Data not available due to confidentiality of student information.

\section{Competing interests}

Authors were employed by the university that implemented the intervention mentioned in the study.

\section{Author details}

${ }^{1}$ School of Teaching and Learning, Minnesota State University, Moorhead 56563, USA. ${ }^{2}$ College of Education, University of Nevada, Reno, USA.

Received: 2 July 2020 Accepted: 26 August 2020

Published online: 16 September 2020

\section{References}

Adesile I, Nordin MS, Kazmi Y, Hussein S (2016) Validating academic integrity survey (AIS): an application of exploratory and confirmatory factor analytic procedures. J Acad Integr 14:149-167. https://doi.org/10.1007/s10805-016-9253-y

Ames C (1992) Achievement goals and the classroom motivational climate. In: Schunk DH, Meece JL (eds) Student perceptions in the classroom. Lawrence Erlbaum Associates, Hillsdale, pp 327-348

Ames C, Archer J (1988) Achievement goals in the classroom: students' learning strategies and motivation processes. J Educ Psychol 80(3):260-267. https://doi.org/10.1037/0022-0663.80.3.260

Anderman EM, Danner F (2008) Achievement goals and academic cheating. Revint Psychol Soc 21(1):155-180

Anderman EM, Griesinger T, Westerfield G (1998) Motivation and cheating during early adolescence. J Educ Psychol 90:84-93

Anderson LW, Krathwohl DR, Bloom BS (2001) A taxonomy for learning, teaching, and assessing: a revision of Bloom's taxonomy of educational objectives. Longman, New York

Aronson E, Mettee DR (1968) Dishonest behavior as a function of differential levels of induced self-esteem. J Pers Soc Psychol 9(2):121-127. https://doi.org/10.1037/h0025853

Ashworth P, Bannister P, Thorne P (1997) Guilty in whose eyes? University students' perceptions of cheating and plagiarism in academic work and assessment. Stud High Educ 22(2):187-203. https://doi.org/10.1080/03075079712331381034

Bouville M (2010) Why is cheating wrong? Stud Philos Educ 29(1):67-76. https://doi.org/10.1007/s11217-009-9148-0

Brimble M, Stevenson-Clarke P (2005) Perceptions of the prevalence and seriousness of academic dishonesty in Australian universities. Aust Educ Res 32(3):19-44

Burrus RT, McGoldrick K, Schuhmann PW (2007) Self-reports of student cheating: does a definition of cheating matter? J Econ Educ 38(1):3-16. https://doi.org/10.3200/JECE.38.1.3-17

Carpenter DD, Harding TS, Finelli CJ (2010) Using research to identify academic dishonesty deterrents among engineering undergraduates. Int J Eng Educ 26(5):1156-1165

Cizek GJ (1999) Cheating on tests: how to do it, detect it, and prevent it. Lawrence Erlbaum Associates, Mahwah

Cohen J (1988) Statistical power analysis for the behavioral sciences, 2nd edn. Lawrence Erlbaum Associates, Hillsdale

Covey MK, Saladin S, Killen PJ (1989) Self-monitoring, surveillance, and incentive effects on cheating. J Soc Psychol 129(5): 673-679. https://doi.org/10.1080/00224545.1989.9713784

Deci EL, Ryan RM (1985) Intrinsic motivation and self-determination in human behavior. Plenum, New York

Deci EL, Ryan RM (1991) A motivational approach to self: integration in personality. In: Dienstbier RA (ed) Current theory and research in motivation, vol. 38. Nebraska symposium on motivation, 1990: perspectives on motivation. Lincoln: University of Nebraska Press, pp 237-288

Deci EL, Ryan RM (2000) The "what" and "why" of goal pursuits: human needs and the self-determination of behavior. Psychol Inq 11:227-268

Downes M (2017) University scandal, reputation and governance. Int J Educ Integr 13(1):1-20. https://doi.org/10.1007/s40979017-0019-0

Elliott ES, Dweck CS (1988) Goals: an approach to motivation and achievement. J Pers Soc Psychol 54(1):5-12. https://doi.org/ $10.1037 / 0022-3514.54 .1 .5$

Ellis PD (2010) The essential guide to effect sizes: statistical power, meta-analysis, and the interpretation of research results. Cambridge University Press, Cambridge. https://doi.org/10.1017/CBO9780511761676

Engler JN, Landau JD, Epstein M (2008) Keeping up with the joneses: students' perceptions of academically dishonest behavior. Teach Psychol 35:99-102. https://doi.org/10.1080/00986280801978418

Faul F, Erdfelder E, Lang A, Buchner A (2007) GPower 3: a flexible statistical power analysis program for the social, behavioral, and biomedical sciences. Behav Res Methods 39(2):175-191. https://doi.org/10.3758/BF03193146

Genereux RL, McLeod BA (1995) Circumstances surrounding cheating: a questionnaire study of college students. Res High Educ 36(6):687-704. https://doi.org/10.1007/BF02208251

Gobbo C, Chi M (1986) How knowledge is structured and used by expert and novice children. Cogn Dev 1(3):221-237. https://doi.org/10.1016/S0885-2014(86)80002-8

Graham MA et al (1994) Cheating at small colleges: an examination of student and faculty attitudes and behaviors. J Coll Stud Dev 35(4):255

Haines VJ, Diekhoff GM, LaBeff EE, Clark RE (1986) College cheating: immaturity, lack of commitment, and the neutralizing attitude. Res High Educ 25(4):342-354

Hughes JM, McCabe DL (2006) Academic misconduct within higher education in Canada. Can J High Educ 36(2):1

Huss MT, Curnyn JP, Roberts SL, Davis SF, Yandell L, Giordano P (1993) Hard driven but not dishonest: cheating and the type a personality. Bull Psychon Soc 31(5):429-430. https://doi.org/10.3758/BF03334952

Ives B, Alama M, Mosora LC, Mosora M, Grosu-Radulescu L, Clinciu Al et al (2017) Patterns and predictors of academic dishonesty in Romanian university students. High Educ 74(5):815-831. https://doi.org/10.1007/s10734-016-0079-8 
Ives B, Nehrkorn A (2019) A research review: post-secondary interventions to improve academic integrity. In: Velliaris DM (ed) Prevention and detection of academic misconduct in higher education. IGl Global, pp 39-62. https://doi.org/10.4018/ 978-1-5225-7531-3.ch002

Jendrek MP (1989) Faculty reactions to academic dishonesty. J Coll Stud Dev 30(5):401

Jensen LA, Arnett JJ, Feldman SS, Cauffman E (2002) It's wrong, but everybody does it: academic dishonesty among high school and college students. Contemp Educ Psychol 27:209-228. https://doi.org/10.1006/ceps.2001.1088

Jordan AE (2001) College student cheating: the role of motivation, perceived norms, attitudes, and knowledge of institutional policy. Ethics Behav 11(3):233-247. https://doi.org/10.1207/S15327019EB1103_3

Kanat-Maymon Y, Benjamin M, Stavsky A, Shoshani A, Roth G (2015) The role of basic need fulfillment in academic dishonesty: a self-determination theory perspective. Contemp Educ Psychol 43:1-9. https://doi.org/10.1016/j.cedpsych. 2015.08.002

Kasser T, Ryan RM (1993) A dark side of the American dream: correlates of financial success as a central life aspiration. J Pers Soc Psychol 65(2):410-422. https://doi.org/10.1037/0022-3514.65.2.410

Kasser T, Ryan RM (1996) Further examining the American dream: differential correlates of intrinsic and extrinsic goals. Personal Soc Psychol Bull 22(3):280-287. https://doi.org/10.1177/0146167296223006

Keener TA, Galvez Peralta M, Smith M, Swager L, Ingles J, Wen S, Barbier M (2019) Student and faculty perceptions: appropriate consequences of lapses in academic integrity in health sciences education. BMC Med Educ 19(1):209. https:// doi.org/10.1186/s12909-019-1645-4

Landis JR, Koch GG (1977) The measurement of observer agreement for categorical data. Biometrics 33(1):159. https://doi.org/ $10.2307 / 2529310$

Lin C-HS, Wen L-YM (2007) Academic dishonesty in higher education: a nationwide study in Taiwan. High Educ 54:85-97. https://doi.org/10.1007/s10734-006-9047-z

Lipsey MW, Puzio K, Yun C, Hebert MA, Steinka-Fry K, Cole MW, Roberts M, Anthony KS, Busick MD (2012) Translating the statistical representation of the effects of education interventions into more readily interpretable forms. National Center for Special Education Research, Institute of Education Sciences, U.S. Department of Education, Washington, DC

Lobel TE, Levanon I (1988) Self-esteem, need for approval, and cheating behavior in children. J Educ Psychol 80(1):122-123. https://doi.org/10.1037/0022-0663.80.1.122

McCabe DL, Treviño LK (1993) Faculty responses to academic dishonesty: the influence of student honor codes. Res High Educ 34(5):647-658. https://doi.org/10.1007/BF00991924

McCabe DL, Treviño LK (1995) Cheating among business students: a challenge for business leaders and educators. J Manag Educ 19(2):205-218

McCabe DL, Treviño LK (1997) Individual and contextual influences on academic dishonesty: a multicampus investigation. Res High Educ 38(3):379-396. https://doi.org/10.1023/A:1024954224675

McCabe DL, Treviño LK, Butterfield KD (1996) The influence of collegiate and corporate codes of conduct on ethics-related behavior in the workplace. Bus Ethics Q 6(4):473-476. https://doi.org/10.2307/3857499

McCabe DL, Treviño LK, Butterfield KD (2001) Cheating in academic institutions: a decade of research. Ethics Behav 11(3):219232. https://doi.org/10.1207/S15327019EB1103_2

McCabe DL, Treviño LK, Butterfield KD (2012) Cheating in college: why students do it and what educators can do about it. Johns Hopkins University Press, Baltimore

Meece JL, Blumenfeld PC, Hoyle RH (1988) Students' goal orientations and cognitive engagement in classroom activities. J Educ Psychol 80(4):514-523. https://doi.org/10.1037/0022-0663.80.4.514

Merriam-Webster (2020) Receptiveness. In: Merriam-Webster.com dictionary Retrieved December 1, 2019, from https://www. merriam-webster.com/dictionary/receptiveness

Munoz-Garcia A, Aviles-Herrera MJ (2014) Effects of academic dishonesty on dimensions of spiritual well-being and stasifaction: a comparative study of secondary school and university students. Assess Eval High Educ 39(3):349-363

Murdock TB, Anderman EM (2006) Motivational perspectives on student cheating: toward an integrated model of academic dishonesty. Educ Psychol 41(3):129-145. https://doi.org/10.1207/s15326985ep4103_1

Murdock TB, Hale NM, Weber MJ (2001) Predictors of cheating among early adolescents: academic and social motivations. Contemp Educ Psychol 26(1):96-115. https://doi.org/10.1006/ceps.2000.1046

Murdock TB, Miller A, Kohlhardt J (2004) Effects of classroom context variables on high school students' judgments of the acceptability and likelihood of cheating. J Educ Psychol 96(4):765-777. https://doi.org/10.1037/0022-0663.96.4.765

Murdock TB, Miller AD, Goetzinger A (2007) Effects of classroom context on university students' judgments about cheating: mediating and moderating processes. Soc Psychol Educ 10(2):141-169. https://doi.org/10.1007/s11218-007-9015-1

National Research Council. 2000. How People Learn: Brain, Mind, Experience, and School: Expanded Edition. Washington, DC: The National Academies Press. https://doi.org/10.17226/9853

Neuendorf KA (2002) The content analysis guidebook. Sage Publications, Thousand Oaks. https://doi.org/10.4135/ 9781071802878

Newstead SE, Franklyn-Stokes A, Armstead P (1996) Individual differences in student cheating. J Educ Psychol 88(2):229-241. https://doi.org/10.1037/0022-0663.88.2.229

Nolen SB (1988) Reasons for studying: motivational orientations and study strategies. Cogn Instr 5(4):269-287. https://doi.org/ 10.1207/s1532690xci0504_2

Nonis S, Swift CO (2001) An examination of the relationship between academic dishonesty and workplace dishonesty: a multicampus investigation. J Educ Bus 77(2):69-77. https://doi.org/10.1080/08832320109599052

Owunwanne D, Rustagi N, Dada R (2010) Students' perceptions of cheating and plagiarism in higher institutions. J Coll Teach Learn 7(11):59-68

Park S (2019) Goal contents as predictors of academic cheating in college students. Ethics Behav:1-12. https://doi.org/10. 1080/10508422.2019.1668275

Pintrich PR (2000) Multiple goals, multiple pathways: the role of goal orientation in learning and achievement. J Educ Psychol 92(3):544-555. https://doi.org/10.1037/0022-0663.92.3.544

Price PC, Jhangiani RS, Chiang I-CA, Leighton C, Cuttler C (2017) Research methods in psychology, 3rd edn. PB Pressbooks 
Rettinger DA, Kramer Y (2009) Situational and personal causes of student cheating. Res High Educ 50(3):293-313. https://doi. org/10.1007/s11162-008-9116-5

Roccas S, Sagiv L, Schwartz SH, Knafo A (2002) The big five personality factors and personal values. Personal Soc Psychol Bull 28(6):789-801. https://doi.org/10.1177/0146167202289008

Saldaña J (2015) The coding manual for qualitative researchers, 3rd edn. Sage Publication, Thousand Oaks

Schmuck P, Kasser T, Ryan RM (2000) Intrinsic and extrinsic goals: their structure and relationship to well-being in German and U.S. college students. Soc Indic Res 50(2):225-241. https://doi.org/10.1023/A:1007084005278

Sheldon KM, Ryan RM, Deci EL, Kasser T (2004) The independent effects of goal contents and motives on well-being: it's both what you pursue and why you pursue it. Personal Soc Psychol Bull 30(4):475-486. https://doi.org/10.1177/ $0146 \mathrm{e} 167203261883$

Sims RL (1993) The relationship between academic dishonesty and unethical business practices. J Educ Bus 68(4):207-211. https://doi.org/10.1080/08832323.1993.10117614

Soutar G, Turner J (2002) Students' preferences for university: a conjoint analysis. Int J Educ Manage 16:40-45. https://doi.org/ $10.1108 / 09513540210415523$

Stern EB, Havlicek L (1986) Academic misconduct: results of faculty and undergraduate student surveys. J Allied Health 15(2): 129-142

Vansteenkiste M, Lens W, Deci EL (2006) Intrinsic versus extrinsic goal contents in self-determination theory: another look at the quality of academic motivation. Educ Psychol 41(1):19-31. https://doi.org/10.1207/s15326985ep4101_4

Vansteenkiste M, Niemiec CP, Soenens B (2010) The development of the five mini-theories of self-determination theory: an historical overview, emerging trends, and future directions. In: Urdan TC, Karabenick SA (eds) Advances in motivation and achievement, vol 16. Emerald Group Publishing Limited, pp 105-165. https://doi.org/10.1108/S07497423(2010)000016A007

Weiss J, Gilbert K, Giordano P, Davis SF (1993) Academic dishonesty, type a behavior, and classroom orientation. Bull Psychon Soc 31(2):101-102. https://doi.org/10.3758/BF03334151

\section{Publisher's Note}

Springer Nature remains neutral with regard to jurisdictional claims in published maps and institutional affiliations.

- fast, convenient online submission

- thorough peer review by experienced researchers in your field

- rapid publication on acceptance

- support for research data, including large and complex data types

- gold Open Access which fosters wider collaboration and increased citations

- maximum visibility for your research: over $100 \mathrm{M}$ website views per year

At $\mathrm{BMC}$, research is always in progress.

Learn more biomedcentral.com/submissions 